\title{
Veterinarians and beekeeping: What roles, expectations and future perspectives? - a review paper
}

\author{
Ivana Tlak Gajger ${ }^{1 *}$, Aránzazu M. Mañes ${ }^{2}$, Giovanni Formato ${ }^{3}$, Michele Mortarino ${ }^{4}$, \\ and Juraj Toporcak ${ }^{5}$ \\ ${ }^{1}$ Department for the Biology and Pathology of Fish and Bees, Faculty of Veterinary Medicine, University of Zagreb, \\ Zagreb, Croatia \\ ${ }^{2}$ Department Animal Health, Complutense University Madrid, Madrid, Spain \\ ${ }^{3}$ Apiculture, Honey Bee Production and Diseases Laboratory, Istituto Zooprofilattico Sperimentale del Lazio e della \\ Toscana "M.Aleandri, Toscana, Italy \\ ${ }^{4}$ Department of Veterinary Medicine, State University of Milan, Lodi, Italy \\ ${ }^{5}$ University of Veterinary Medicine and Pharmacy, Kosice, Slovakia
}

TLAK GAJGER, I., A. M. MAÑES, G. FORMATO, M. MORTARINO, J. TOPORCAK: Veterinarians and beekeeping: What roles, expectations and future perspectives? - a review paper. Vet. arhiv 91, 437-443, 2021.

\section{ABSTRACT}

Apiculture is an important economy sector, facing a real health crisis. Honeybees, as well as other insect pollinator populations have been in decline over recent decades, and diseases are one of the principal challenges. To face this situation, public and private veterinary services are needed to manage surveillance, control, eradication and prevention measures of honeybee diseases within their territories, in close collaboration with beekeepers and farmers. It is necessary urgently to clarify the current problems and threats to apiculture in the public health sector. Due to possible interactions between bee health and production, the negative effects of environmental xenobiotics and climate change, this field must be considered as an interdisciplinary research issue. Moreover, honeybee veterinary medicine is increasingly engaged in the One Health approach, due to the possibility that the poor health of honeybee colonies affects human life. This review identified the key veterinarian roles, gaps in their higher education curriculum, as well as the necessity for research linkage between expectations and professional perspectives.

Key words: honeybee colonies; veterinary medicine; One Health; disease management; beekeepers

\section{Introduction}

Modern beekeeping is facing numerous challenges all over the world due to a variety of factors, mainly related to globalization, different form of human management, socio-economic factors, agrochemical pollution, and environmental changes, such as global warming (SMART et al., 2016). In addition to this, diseases and pests (GENERSCH et al., 2010), as well as new pathogens (e.g. Nosema ceranae) (BURNHAM, 2019) and invasive species (such as the Small Hive Beetle -SHB, and Asian yellowlegs hornet - Vespa velutina) are threatening the health of honeybee

\footnotetext{
*Corresponding author:

Ivana Tlak Gajger, PhD, DVM, Department for Biology and Pathology of Fish and Bees, Faculty of Veterinary Medicine, University of Zagreb, Heinzelova 55, 10000 Zagreb, Croatia, Phone: +385 12390 151; Fax: +385 12390 211; E-mail: ivana.tlak@vef.hr
} 
colonies (LAURINO et al., 2020). Owing to the negative impact of parasites, pathogens and pesticides on honeybee mortality, research strategies are oriented towards epidemiological studies to find possible interactions between these causes of the weakening or loss of colonies, using experimental and empirical models, in different geographical and climatic regions (MORITZ et al., 2010; LAURENT et al., 2015). Special attention is being paid to field health monitoring of colonies, standardized early, correct, and quick laboratory diagnostic methods, new treatments and sustainable ideas, procedures for disease prevention measures and biosecurity measures in beekeeping (SCHURR et al., 2017; PIETROPAOLI et al., 2020; PIETROPAOLI and FORMATO, 2020, SCOTT et al., 2020; TLAK GAJGER et al., 2020; PIETROPAOLI et al., 2021). Also, screening of different apicultural practices and finding new selection tools are currently part of the research goals (TLAK GAJGER et al., 2017; PIETROPAOLI et al., 2020).

All these objectives can be achieved using multidisciplinary strategies, such as a combination of harmonized protocols of scientific research in field and laboratory conditions, food safety control, as well as socio-economic analysis of the honeybee products' market. In this context, correct and in time colony and apiary management should encompass a wider vision, where the productivity and profitability aspects of beekeeping are linked to a holistic veterinary approach, in order to protect honeybees, humans and environmental health.

Honeybee colonies are husbandry animals: according to the World Organization for Animal Health (OIE, 2018) and the European Union (EU) legislation (- European Commission, EC, 2016) bees are classified as terrestrial animals and therefore they fall under veterinary care. Apiaries need veterinarians just as other animal farms do (DITTES et al., 2020; TLAK GAJGER, 2021; VIDALNAQUET, 2015). Education in the biomedical field is extremely important to understand the principles of honeybee colony losses, and enable the use of apitechnical, as well as therapeutical measures for colony welfare and health. Under the concept of the One Health umbrella, veterinary science can combine its efforts with other scientific disciplines and professionals (e.g. policy makers, farmers) to ensure healthy honeybee products and guarantee the safety of pollinators and avoid a decline in honeybee numbers (DONKERSLEY et al., 2020; JONGH et al., 2020).

The European honeybee (Apis mellifera L.) is an important and efficient, ecological species, contributing directly to human nutrition and health, as well as to global economic sustainability (POTTS et al., 2010). Furthermore, honeybee pollination is essential for agriculture and the environment, ensuring plant reproduction and biodiversity in managed and natural ecosystems. Honeybee colonies provide a wide variety of hive products: bee venom, royal jelly, beeswax, honey, pollen, and propolis, as well as queens and new colonies. There is a constant decline in wild nonhoneybee insect pollinators, and as a result the importance of beekeepers and managed honeybee colonies is increasing. Moreover, beekeeping is an important sector in the development of rural areas and in any nation's agriculture and biodiversity. It is important to identify, validate and implement good beekeeping practices in apiaries and honey houses (RIVERA-GOMIS et al., 2019; TLAK GAJGER, 2019). These stainable management strategies are always enhanced by international collaboration, as well as the development and maintenance of good practices and biosecurity measures in apiaries.

A recent investigation (IATRIDOU et al., 2019) carried out in cooperation with the European Association of Establishments for Veterinary Education (EAEVE), the Federation of Veterinarians in Europe (FVE) and some experienced lecturers from Veterinary Faculties, looked into whether the biology and diseases of honeybees and other beneficial insects are included in the study curricula in the 77 European veterinary education establishments - the Faculties of Veterinary Medicine (FVM), in the EU territory, as well as in the European Free Trade Area (EFTA). The results showed that $57 \%$ of FVMs include teaching regarding honeybee veterinary medicine in their core study curriculum, but only $43 \%$ of them had these topics as separate subjects.

Focusing on data collected from the 68 FVMs with accreditation or approval status granted by 
the European System of Evaluation of Veterinary Training (ESEVT), 35\% of them offer training on honeybee health as a separate subject, $43 \%$ as part of other subjects, and $22 \%$ do not include these subjects in their curriculum. Nineteen out of 77 veterinary education establishments $(25 \%)$ regularly organize postgraduate training courses in the field of beekeeping and honeybee health veterinary care. Postgraduate programmes in honeybee veterinary medicine are available in 13 European countries, and the duration level of these is from "one day" courses to Master's specialization programmes or $\mathrm{PhD}$ studies.

There is a clear geographical difference in the teaching. While in the north-western countries only about half of the FVMs include honeybee health, apiculture and honeybee product quality and welfare control in their undergraduate curricula, in the eastern, central and southern European countries, most of the FVMs traditionally incorporate honeybee veterinary medicine in their undergraduate curriculum. At least one FVM in each country includes teaching of honeybee veterinary medicine in their curricula. Lectures and practice in honeybee veterinary medicine is situated mostly in the $8^{\text {th }}$ semester, or in the last semesters of study, and in the curricula the compulsory and elective study hours are allocated as follows: 1-10 hours (18\%), 11-25 hours (32\%), 26-40 hours (18\%), and 106 hours $(2 \%)$.

\section{Vets4Bees International}

At the initiative of the Italian Veterinary Scientific Society for Beekeeping (Società Scientifica Veterinaria per l'Apicoltura, SVETAP) on 12 February 2019, in Rome, a consortium of Veterinarians for Bees International (Vets4Bees Int.) was established. The main tasks of this first organized international working group are to educate and inform veterinarians dealing with honeybees, as well as to promote honeybee veterinary science and transfer knowledge to beekeepers and other stakeholders (http://vets4bees. uvlf.sk/). This was preceded by a workshop entitled "Veterinarians and Beekeeping: What are the Rules and Expectations?" An international group of veterinarians took part in the Workshop, and the meeting involved veterinarians from seven countries (Croatia, Italy, Slovakia, Slovenia, Spain, Turkey and the USA). The workshop also included the presence and presentations of the President of FVE and the General Secretary of Apimondia.

Each participant in the workshop presented the national rules and expectations of veterinarians in their own country. The higher concerns during discussion were related to the obligation for veterinary prescription of medicines registered for honeybees and authorized for apiary use in different countries, as well as the training of veterinarians at University level, especially concerning honeybee pathologies.

At the end of the meeting, the participants established a new world association of veterinarians known as "Vet4Bees". At the same time, a document containing the goals of "Vet4Bees" was signed. The goals were the following:

to protect bee health in the context of the OneHealth approach;

to hold regular meetings to achieve these goals;

to offer training for veterinarians and veterinary students in apiculture;

to deepen the understanding of different training methods and educational opportunities in apiculture for veterinarians at an international level;

to define guidelines for Good Veterinary Practices in apiculture;

to strengthen relationships between the Veterinary profession and the beekeeping sector;

and to promote and harmonize responsible distribution and use of veterinary medicines.

\section{Roles and expectations}

Increasing the competencies of veterinarians will ensure the health and welfare of honeybee colonies, better relationships and cooperation with beekeepers, and safe honeybee products for consumers. Moreover, in the long term, the establishment of global networks of specialized "honeybee medicine" veterinarians will assist beekeepers with proper healthcare support for their work in apiaries and/or in the apiary's auxiliary buildings, and in relation to transport welfare rules. 


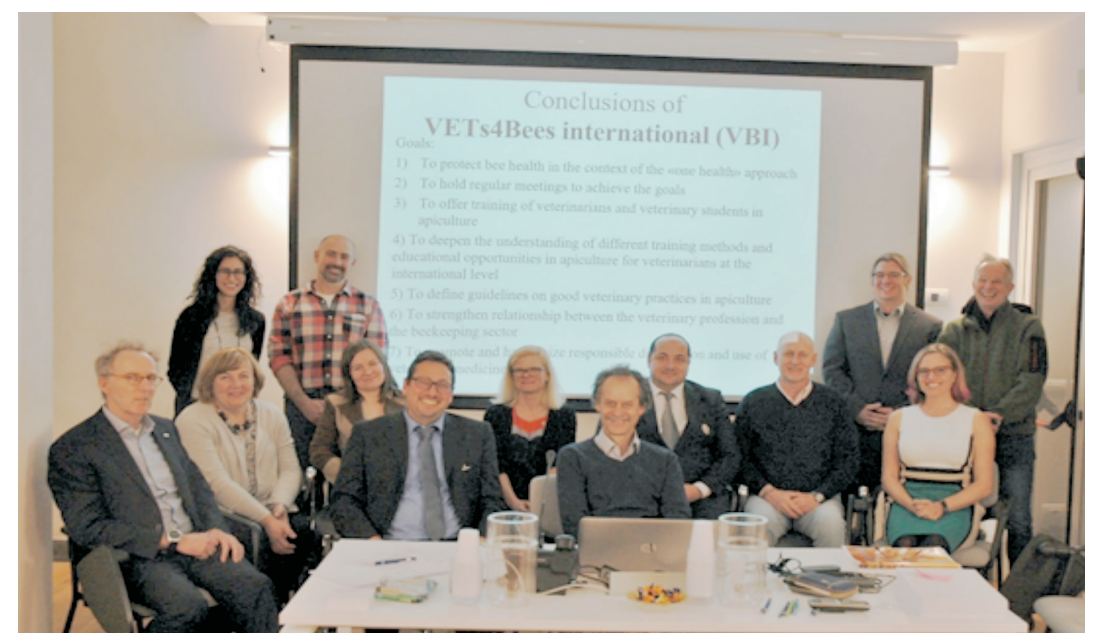

Management committee members of the first International Vets4Bees consortium

As beekeeping is one of the most dynamic sectors of agricultural production, it is very important for beekeepers to implement good beekeeping practices, which also include using veterinary medicine products (VMPs), disease management and training (RIVERA-GOMIS et al., 2019). For veterinarians, the main concern is to create guidelines for good veterinary practice at the apiary (TOMLJANOVIĆ et al., 2012; HAYES, 2014).

The veterinarian's main tasks and the core competences that a veterinarian must acquire in order to be qualified to practise in apiaries include: clinical inspection of a honeybee colony, identifying signs of disease in brood and adult bees, official sampling, and filling out the formal cover documentation for the delivery of samples to an authorized diagnostic laboratory, basic laboratory examinations, and knowledge of serious disease control, and preventive and eradication measures (CHAUZAT, 2014; TLAK GAJGER, 2020).

In addition, the veterinarian must be able to inspect the beekeepers' records, take proper anamnestic data for a proper diagnosis, and advise about disease control and prophylaxis, as well as prescribe the proper veterinary medicine products (MUTINELLI, 2016). These tasks demand good interpersonal communication skills and practical experience with beekeepers in-field. Good communication between veterinarians and honeybee colony owners is really helpful to help them understand complex issues such as adult bee behaviour, competent application of therapy, or the possible causes of honeybee losses, but it is also essential to implement long-term apiary management solutions as well as integral pest and disease control.

The veterinarian and veterinary services are also responsible for informing beekeepers about the transport and trade of honeybee colonies, honeybee queens and bumblebee colonies, in line with international standards, and to ensure the correct application of all national legislation.

Acaricides, in the form of registered VMPs to control Varroa destructor mite populations, are the only therapy approved for use in apiaries in the EU. The use of antibiotics in apiaries is not allowed in the EU area, whereas in some other parts of the world, e.g. the USA, they can be used under veterinary prescription and very restricted conditions. The veterinarian is the only one who is able to select the right VMP for honeybee colony treatment, and to issue proper recomendations to beekeepers on their responsible use, and information about withdrawal periods, possible side effects such as residues, and risks related to the development of resistance (RIVERA-GOMIS et al., 2019; TLAK GAJGER, 2019).

Updated knowledge is essential for veterinarians, so life-long continuing education courses can foster professionalism in the veterinary medicine field. 


\section{Perspectives}

The promotion and harmonisation of veterinary medicine study curricula is needed to ensure the correct and harmonized implementation of teaching in honeybee veterinary medicine (IATRIDOU et al., 2019). The adequate education of veterinary students should include mandatory topics in the undergraduate core curriculum of all FVMs, including: the basics of apiculture, beekeeping techniques, the biology and pathology of honey bees, and practical demonstrations at the apiary level. Moreover, the development of postgraduate opportunities, such as international Master's studies in honeybee veterinary medicine, is a necessity. For this reason, harmonised international programmes at the EU level for graduate veterinarians should be established, with consideration of the needs of the market. This would enable graduate veterinarians to become proficient in compulsory knowledge and skills, and consequently to be ready to practise veterinary medicine in beekeeping. That means to have basic knowledge and experience of hands on skills, to be able to examine, sample, diagnose and treat honeybee colonies, as well as to ensure the safety of their hive products.

Policy makers and industry should support the apiculture sector, improving the legislative framework, supporting laboratories specialised in the diagnosis of honeybee diseases, and providing for the honeybee products' market. For their part, veterinarians should implement solutions for aspects of their own competence, such as: keeping beekeeping registers up to date, verifying the proper management of honey bee diseases (especially the notifiable ones), verifying the proper application of biosecurity measures, promoting innovations in beekeeping (e.g. the adoption of mobile applications with apiary maps).

New associations and/or networks of veterinary organisations could encourage beekeepers to look for veterinary support to solve threats to the health of their honeybees, to ask for educational training, and to establish good relationships between veterinarians and beekeepers' associations in general.

\section{Conclusion}

By implementing the One health approach through the application of good veterinary, beekeeping and environmental practices, Vet4Bees may guarantee the safety of those honeybee products that are used for human consumption, as well as sustainable apiculture. This modern strategy composes and implements programs, measures, legislation, acts and studies, where different management sectors work together to achieve better shared public health outcomes. In this way, as well as improving educational programmes and promoting new international postgraduate opportunities, veterinarians will further contribute to the transfer of science into their regular practice, and consequently to guarantee the sustainability and availability of safe and nutritious food in the future ecosystem.

\section{References}

BURNHAM, A. J. (2019): Scientific Advances in Controlling Nosema ceranae (Microsporidia) Infections in honey bees (Apis mellifera). Front. Vet. Sci. 6, 79.

DOI: 10.3389/fvets.2019.00079

CHAUZAT, M.-P. (2014): Sampling and shipment of samples. In: Ritter, W. (ed.), Bee health and veterinarians. OIE, Paris, 103-111.

DITTES, J., H. AUPPERLE-LELLBACH, M. O. SCHÄFER, C. K. W. MÜLLING, I. U. EMMERICH (2020): Veterinary diagnostics approach of common virus diseases in adult honeybees. Vet. Sci. 7, 159.

DONKERSLEY, P., ELSNER-ADAMS, E., MADERSON, S. (2020): A One-Health model for reversing honeybee (Apis mellifera L.) decline. Vet. Sci. 7, 119.

EUROPEAN COMMISSION (EC) (2016) - Regulation (EU) 2016/429 of the European Parliament and of the Council of 9 March 2016 on transmissible animal diseases and amending and repealing certain acts in the area of animal health ('Animal Health Law'). Off. J. Eur. Union, L 84, p. 208. Available at: https://eur-lex.europa.eu/legalcontent/ EN/TXT/?uri $=$ uriserv\%3AOJ.L_.2016.084.01.0001.01

GENERSCH, E., I. FRIES, J. EVANS (2010): Honey bee diseases overview. J. Invertebr. Pathol. 103, S2-S4.

HAYES, G. W. (2014): Inspections of and sanitary visits to honey bee colonies. In: Bee health and veterinarians. (Ritter, W., Ed.), OIE, Paris, 95-101.

IATRIDOU, D., L. POHL, I. TLAK GAJGER, N. DE BRIYNE, A. BRAVO, J. SAUNDERS (2019): Mapping the teaching of the honeybee veterinary medicine in the European Union and European free trade area. Vet. Rec. Open 6, e000343.

DOI: $10.1136 /$ vetreco-2019-000343 
JONGH, E. J., S. L. HARPER, S. S. YAMAMOTO, C. J. WRIGHT, C. W. WILKINSON, S. GHOSH, S. J. G. OTTO (2020): One Health, One Hive: A scoping review of honey bees, climate change, pollutants, and antimicrobial resistance. BioRxiv 2020.11.03.366377;

DOI: $10.1101 / 2020.11 .03 .366377$

LAURENT, M., P. HENDRIKX, M. RIBIERE-CHABERT, M. P. CHAUZAT (2015). A pan-European epidemiological study on honeybee colony losses 2012-2014. EPILOBEE Report. Available from https://ec.europa.eu/food/sites/food/ files/animals/docs/la_bees_epilobee-report_2012-2014.pdf

LAURINO, D., S. LIOY, L. CARISIO, A. MANINO, M. PORPORATO (2020): Vespa velutina: An alien driver of honey bee colony losses. Diversity 2020, 12, 5.

MORITZ, R. F. A., J. de MIRANDA, I. FRIES, Y. Le CONTE, P. NEUMANN, R. J. PAXTON (2010): Research strategies to improve honeybee health in Europe. Apidologie 41, 227242.

DOI: $10.1051 /$ apido/2010010

MUTINELLI, F. (2016): Veterinary medicinal products to control Varroa destructor in honeybee colonies (Apis mellifera) and related EU legislation - an update. J. Apic. Res. 55, 1, 1-11.

DOI: $10.1080 / 00218839.2016 .1172694$

OIE (2018): Manual of Diagnostic Tests and Vaccines for Terrestrial Animals: mammals, birds and bees, $8^{\text {th }}$ ed. World Organisation For Animal Health. Paris, France. Available at: www.oie.int/standard-setting/terrestrial-manual/accessonline

PIETROPAOLI, M., G. FORMATO (2020): Good beekeeping practices: FAO practical manual on how to identify and control the main diseases of the honeybee (Apis mellifera). Available at: http://www.fao.org/policy-support/tools-andpublications/resources-details/ar/c/1393274/

PIETROPAOLI, M., SMODIŠ ŠKERL, M. I., CAZIER, J., RIVIERE, M.-P., TIOZZO, B., EGGENHOEFFNER, R., GREGORC, A., HAEFEKER, W., HIGES, M., RIBARITS, A., MUZ, M.N., VEJSNÆS, F., FORMATO, G. (2020): BPRACTICES project: towards a sustainable European beekeeping. Bee world 97, 3, 66-69.

PIETROPAOLI, M., I. TLAK GAJGER, C. COSTA, D. GERULA, J. WILDE, N. ADJLANE, P. A. SÁNCHEZ, M. I. SMODIŠ ŠKERL, J. BUBNIČ, G. FORMATO (2021): Evaluation of two commonly used field tests to assess Varroa destructor infestation on honey bee (Apis mellifera) colonies. Appl. Sci. 11, 4458.

DOI: org/10.3390/app11104458

POTTS, S. G., J. C. BIESMEIJER, C. KREMEN, P. NEUMANN, O. SCHWEIGER, W. E. KUNIN (2010): Global pollinator declines: Trends, impacts and drivers. Trend Ecol. Evol. 25, 345-353.

RIVERA-GOMIS, J., J. BUBNIC, A. RIBARITS, R. MOOSBECKHOFER, O. ALBER, P. KOZMUS, R. JANNONI-SEBASTIANINI, W. HAEFEKER, H.
KÖGLBERGER, M. I. SMODIS SKERL, B. TIOZZO, M. PIETROPAOLI, J. LUBROTH, E. RAIZMAN, C. LIETAER, R. ZILLI, R. EGGENHOEFFNER, M. HIGES, M. N. MUZ, C. D'ASCENZI, M. P. RIVIERE, A. GREGORC, J. CAZIER, E. HASSLER, J. WILKES, G. FORMATO (2019): Good farming practices in apiculture. OIE Scientific and Technical Review Vol. 38, 3, 1112201900160-EN.

SCHURR, F., N. COUGOULE, M.-P. RIVIE'RE, M. RIBIERECHABERT, H. ACHOUR, D. ADAM, C. CASTILLO, D. C. DE GRAAF, E. FORSGREN, A. GRANATO, S. HEINIKAINEN, J. JUROVCIKOVA, P. KRYGER, C. MANSON, M.-F. MENARD, S. PERENNES, M. O. SCHAFER, E. SAN MIGUEL IBANEZ, J. SILVA, I. TLAK GAJGER, V. TOMKIES, I. TOPLAK, A. VIRY, D. ZDANSKA, E. DUBOIS (2017): Trueness and precision of the real time RT-PCR method for quantifying the chronic bee paralysis virus genome in bee homogenates evaluated by a comparative inter-laboratory study. J. Virol. Methods 248, 217-225.

DOI: 10.1016/j.jviromet.2017.07.013

SCOTT, A., HASSLER, E., CAZIER, J., WILKES, J., FORMATO, G., MACDONALD, P., RUBINIG, M., BRAGA, A.R., PITTIGLIO, C. (2020): Data mining varroa: sharing insight from users of apiary management software in the United States. Bee World 97, 78-83.

DOI: 10.1080/0005772X.2020.1770153

SMART, M., J. PETTIS, N. RICE, Z. BROWNING, M. SPIVAK (2016): Linking measures of colony and individual honey bee health to survival among apiaries exposed to varying agricultural land use. PLoS ONE 11, 3, e0152685.

DOI: 10.1371/journal.pone.0152685

TLAK GAJGER, I., M. SAKAČ, A. GREGORC (2017): Impact of Thiamethoxam on Honey Bee Qeeen (Apis mellifera) reproductive morphology and physiology. Bull. Environ Contam. Toxicol. 99, 3, 297-302.

DOI: $10.1007 / \mathrm{s} 00128-017-2144-0$

TLAK GAJGER, I. (2019a): How Vets4Bees work benefits wider society? $32^{\text {nd }}$ General Assembly of European Association of Establishments for Veterinary Education, $30-31^{\text {st }}$ of May 2019, Zagreb, Croatia, Book of abstracts, 40-41.

TLAK GAJGER, I. (2020): Veterinary Medicine in field of beekeeping. Hrvatski Veterinarski Vjesnik 28, 4, 44-51 (in Croatian).

TLAK GAJGER, I., J. VLAINIĆ, P. ŠOŠTARIĆ, J. PREŠERN, J. BUBNIČ, M. I. SMODIŠ ŠKERL (2020): Effects on some therapeutical, biochemical, and immunological parameters of honey bee (Apis mellifera) exposed to probiotic treatments, in field and laboratory conditions. Insects 11, 9, 638 .

DOI: $10.3390 /$ insects 11090638 
TLAK GAJGER, I. (2021): Honeybee diseases in contemporary production. Faculty of Veterinary Medicine University of Zagreb, Zagreb.

TOMLJANOVIĆ, Z., I. TLAK GAJGER, V. SANTRAČ (2012): Good veterinary practice in apiary. Bayer Animal Health, Zagreb (in Croatian).
VIDAL-NAQUET, N. (2015): Honeybee Veterinary Medicine: Apis mellifera L. 5m Publishing Benchmark House, Sheffield, UK.

Received: 19 January 2021

Accepted: 8 July 2021

TLAK GAJGER, I., A. M. MAÑES, G. FORMATO, M. MORTARINO, J. TOPORCAK: Veterinari i pčelarstvo: Koje su uloge, očekivanja i perspektive u budućnosti? - pregledni rad. Vet. arhiv 91, 437-443, 2021. SAŽETAK

Pčelarstvo je važan sektor gospodarstva koji se suočava sa zdravstvenom krizom. Zajednice medonosne pčele, kao i populacije drugih kukaca oprašivača se smanjuju posljednjih desetljeća. Bolesti se smatraju jednim od glavnih uzroka gubitaka u pčelarstvu. Kako bi se suočili s tim problemom potrebno je povoditi veterinarski nadzor, kontroliranje, suzbijanje i preveniranje bolesti pčela uključivanjem javnih i privatnih veterinarskih organizacija na području njihova djelovanja i u bliskoj suradnji s pčelarima i poljoprivrednicima. Nužno je potrebno osvijestiti aktualnu problematiku i ugroženost pčelarstva u javnozdravstvenom sektoru. Zbog mogućih negativnih učinaka ksenobiotika iz okoliša i klimatskih promjena na zdravlje i proizvodnju pčelinjih zajednica ovo područje zahtjeva provedbu intradisciplinarnih istraživanja. Štoviše, veterinarska medicina u području zdravlja zajednica medonosne pčele zauzima iznimno važan pristup Jednog zdravlja upravo zbog mogućnosti da narušeno zdravlje pčelinjih zajednica može negativno utjecati na zdravlje ljudi. U ovom radu istaknute su glavne uloge veterinara u pčelarstvu, nedostatci u kurikulima studijskih programa veterinarske medicine visokoobrazovnih ustanova i nužnosti provedbe istraživanja koja povezuju očekivanja i stručne perspektive.

Ključne riječi: zajednice medonosne pčele, veterinarska medicina, Jedno zdravlje, kontroliranje bolesti, pčelari 
